Горный информационно-аналитический бюллетень (научно-технический журнал). - 2020. - № 3. - С. 58-73. - DOI: 10.25018/0236-1493-2020-3-0-58-73.

3. Семин М.А., Исаевич А.Г., Жихарев С.Я. Исследование оседания пыли калийной соли в горной выработке // Физико-технические проблемы разработки полезных ископаемых. - 2021. - № 2. - С. 178191. - DOI: 10.15372/FTPRPI20210218.

4. Зайцев А.В., Бородавкин Д.А., Поляков И.В. Обеспечение безопасных условий труда по фактору микроклимата для условий глубокого калийного рудника // Горное эхо. - 2020. - № 1 (78). - С. 72 79. - DOI: 10.7242/echo.2020.1.16.

5. Зайцев А.В., Семин М.А., Клюкин Ю.А. Исследование критериев нормирования микроклиматических условий в горных выработках // Горный информационно-аналитический бюллетень (научнотехнический журнал). - 2015. - № 12. - С. 151-156.

6. Устинова О.Ю., Костарев В.Г., Алексеев В.Б., Власова Е.М., Носов А.Е., Зайцев А.В., Левин Л.Ю. Влияние условий труда на функциональное состояние организма работников, занятых на добыче нефти термошахтным способом // Гигиена и санитария. - 2020. - Т. 99, № 11. - С. 1222-1229.

7. Левин Л.Ю., Семин М.А., Зайцев А.В. Контроль и прогноз формирования ледопородного ограждения с использованием оптоволоконных технологий // Стратегия и процессы освоения георесурсов: сб. науч. тр. Вып. 14 / ГИ УрО РАН. - Пермь, 2016. - С. 236-238.

8. Левин Л.Ю., Семин М.А., Зайцев А.В. Калибровка теплофизических свойств породного массива при моделировании формирования ледопородного ограждения строящихся шахтных стволов // Физикотехнические проблемы разработки полезных ископаемых. - 2019. - № 1. - С. 172-184. - DOI: $\underline{\text { 10.15372/FTPRPI20190119. }}$.

9. Левин Л.Ю., Зайцев А.В., Семин М.А. Контроль теплового режима породного массива на основе применения оптоволоконных технологий мониторинга температур в скважинах // Горное эхо. -2016. - № 1 (62). - C. 35-37.

10. Kostina A., Zhelnin M., Plekhov O., Panteleev I., Levin L., Semin M. Applicability of Vyalov's equations to ice wall strength estimation // Frattura ed integrita strutturale. - 2020. - V. 14, № 53. - P. 394-405. - DOI: 10.3221/IGF-ESIS.53.30.

11. Инструкция по расчету параметров, контролю и управлению искусственным замораживанием горных пород при строительстве шахтных стволов на калийных рудниках ОАО «Беларуськалий. Пермь; Солигорск, 2019. - 65 с.

12. Левин Л.Ю., Кормщиков Д.С., Гришин Е.Л. Исследование процессов изменения рудничной атмосферы для определения причин произошедшего группового несчастного случая на одном из рудников РФ // Горное эхо. - 2020. - № 3 (80). - C. 115-119. - DOI: 10.7242/echo.2020.3.22.

13. Шалимов А.В., Левин Л.Ю., Исаевич А.Г., Семин М.А. Исследование влияния калийного аэрозоля на влажность и ионизацию воздуха при проветривании хранилищ сельскохозяйственной продукции // Горное эхо. - 2018. - № 3 (72). - С. 42-49.

14. Костина А.А., Желнин М.С., Плехов О.А., Клюкин Ю.А. Связанная термогидромеханическая модель фильтрации нефти в пористой среде // XXI Зимняя школа по механике сплошных сред: тез. докл. / ИМСС УрО РАН. - Пермь, 2019. - С. 159.

15. Левин Л.Ю., Зайцев А.В., Д.С. Кормщиков, Семин М.А. Поездка в высшую школу технических наук им. Георга Агриколы // Горное эхо. - 2018. - № 3 (72). - С. 55-57.

\title{
ОСОБЕННОСТИ ТЕПЛОФИЗИЧЕСКОГО РАСЧЕТА ЛЕДОПОРОДНЫХ ОГРАЖДЕНИЙ ШАХТНЫХ СТВОЛОВ РУДНИКА ГРЕМЯЧИНСКОГО ГОК
}

\author{
А.А. Оглоблина ${ }^{1}$, А.В. Пугин ${ }^{1}$, И.В. Поляков ${ }^{2}$ \\ ${ }^{I}$ Горный институт УрО РАН, г. Пермь \\ ${ }^{2}$ ООО «ЕвроХим-ВолгаКалий»
}

\begin{abstract}
Аннотация: В статье описаны особенности параметризации теплофизических моделей для шахтных стволов калийного рудника Гремячинского ГОКа. Описаны параметры, подвергающиеся калибровке, и алгоритм выполнения калибровки теплофизической модели.

Ключевые слова: Гремячинский ГОК, искусственное замораживание пород, ледопородное ограждение, теплофизическая модель, калибровка.
\end{abstract}


Искусственное замораживание горных пород при строительстве шахтных стволов применяется в сложных инженерно-геологических и гидрогеологических условиях для предотвращения аварийных ситуаций, связанных с проникновением воды из водоносных горизонтов в забой ствола [1-3]. При строительстве шахтных стволов рудника Гремячинского Горно-обогатительного комбината (ГОКа) искусственное замораживание горных пород использовалось для создания ледопородного ограждения (ЛПО) вокруг горной выработки, так как в процессе гидрогеологических исследований на участке расположения шахтных стволов в интервале глубин 0,0-830,0 м ранее было выделено 6 водоносных горизонтов и 6 водоупорных горизонтов.

С целью выполнения оценок состояния ЛПО шахтных стволов Гремячинского ГОКа было необходимо разработать действующие теплофизические модели, описывающие среду (замороженный слоистый массив горных пород, вмещающих шахтные стволы), происходящие в ней процессы теплопереноса.

Основу теплофизической модели составляет укрупненная слоистая модель среды. Объединение слоев горных пород в укрупненные литологические разности производилось в результате совместного анализа геологических, гидрогеологических данных и показаний системы термометрического контроля в начальный период замораживания. Укрупнение слоев горных пород, слагающих геологический разрез на участке строительства ствола, производилось объединением их в слои мощностью более 5 м таким образом, чтобы в состав укрупненного слоя входили породы с близким гранулометрическим составом, физико-механическими и теплофизическими свойствами.

В силу различий теплофизических свойств различные слои горных пород демонстрировали разную динамику охлаждения и промерзания, что можно было увидеть по данным мониторинга температуры на контрольно-термических скважинах. Это позволило использовать данные с контрольных скважин в качестве дополнительной определяющей информации при укрупнении слоев теплофизической модели. Впоследствии каждый из укрупненных слоев демонстрировал свою динамику замерзания, но по прошествии длительного времени различия между соседними слоями стирались, а кривые температуры в контрольно-термических скважинах имели меньшие градиенты. Это обусловлено вертикальными теплоперетоками между слоями пород.

В результате анализа совокупности данных в разрезе участка шахтных стволов выделено 19 укрупненных слоев, которые составили основу теплофизической модели (рис. 1).

При параметризации модели каждому слою ставился в соответствие отдельный набор физико-механических и теплофизических параметров, присущий преобладающей в нем литологической разности и отвечающий за распространение отрицательных температур от замораживающих колонок вглубь массива и за фазовое превращение воды в лед в порах и трещинах породы.

В дальнейшем теплофизические характеристики слоев подвергались калибровке $[4,5]$, чтобы обеспечить требуемую невязку модельного поля с показаниями системы термометрического контроля в контрольно-термических (КТ) скважинах на заданные моменты времени. В целом калибровка может производиться как вручную, так и автоматически с помощью алгоритмов, основанных на решении обратной задачи Стефана с движущейся границей фазового перехода воды в лед $[6,7]$. 


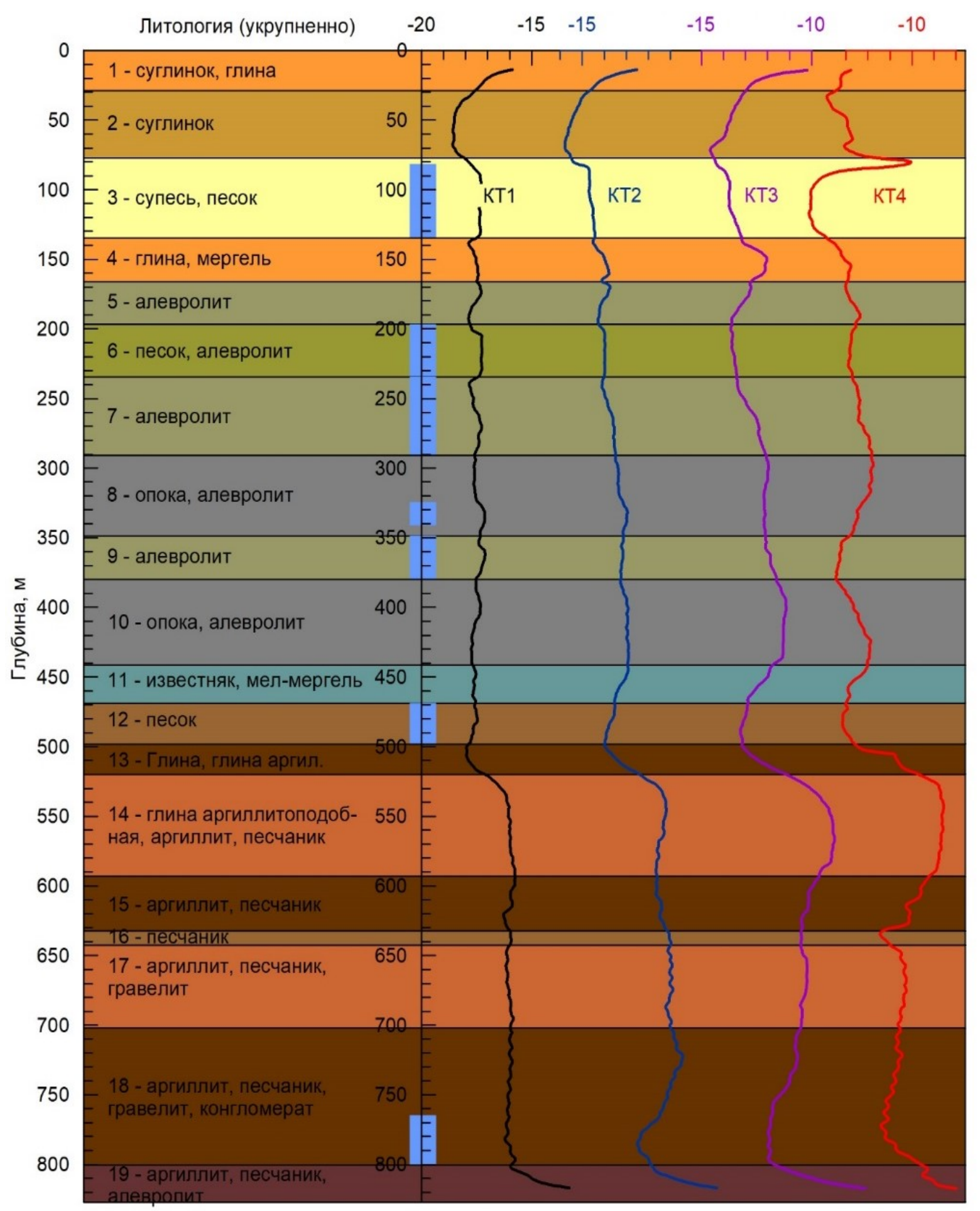

Рис. 1. Укрупненные слои теплофизической модели для условий шахтных стволов с нанесенным распределением температур в контрольно-термических скважинах и обводненными интервалами (синяя заливка)

В программном комплексе «FrozenWall» [8] в процессе калибровки модели изменению подвергаются три ключевых параметра модели:

1) температуропроводность горной породы в зоне льда;

2) температуропроводность горной породы в зоне охлаждения;

3) весовая влажность породы (в смысле Н.А. Цытовича [9]). 
Первоначально для каждого калибруемого параметра определяется диапазон допустимых значений. Калибровка каждого слоя начальной теплофизической модели выполняется по следующему алгоритму:

1) на первой итерации все расчеты выполняются при исходных значениях калибруемых параметров, для чего на заданную дату калибровки рассчитывается поле температур и его отклонения от значений, измеренных в КТ скважинах;

2) первыми калибруются значения теплопроводности породы в зоне льда и в зоне охлаждения; анализируя отклонения, программа или специалист принимают одно из трех решений: 1) если отклонения температур по всем КТ скважинам имеют отрицательный знак, значит модельные температуры ниже измеренных (по модельным данным массив переморожен сильнее), следовательно, необходимо уменьшить калибруемое значение теплопроводности, которое должно при этом находиться в диапазоне между текущим и исходным значением; 2) если отклонения температур по всем КТ скважинам имеют положительный знак, значит модельные температуры выше измеренных (по модельным данным массив переморожен слабее), следовательно, необходимо увеличить калибруемое значение теплопроводности пропорционально отклонениям; 3) если отклонения температур по всем КТ скважинам имеют знакопеременный характер, значит модельные температуры близки к измеренным, в этом случае необходимо продолжить калибровку, незначительно изменяя значения теплопроводностей относительно текущего значения в положительную и отрицательную стороны;

3) определив значения, при которых отклонения модельных температур от измеренных имеют наименьшие значения (локальный минимум функционала среднеквадратической невязки температур), переходят к аналогичной калибровке значения весовой влажности; удельные теплоемкости породы в зоне льда и зоне охлаждения при этом пересчитываются в зависимости от влажности, а теплопроводности изменяются таким образом, чтобы обеспечить неизменность значений температуропроводности породы в зоне льда и зоне охлаждения;

4) в итоге после определения влажности, оптимальной с точки зрения минимизации отклонений модельных и измеренных температур, специалист может произвести тонкую настройку модели, проведя серию расчетов, отклоняя температуропроводности и влажности на незначительную величину в сторону уменьшения и увеличения для проверки того, действительно ли при данных значениях отклонения температур минимальны по модулю.

Критерием успешной калибровки также является попадание отклонений модельных значений температур от измеренных в каждом слое в диапазон допустимой (заданной) погрешности по модулю (в метрике Чебышева, С) и в среднеквадратическом выражении (метрика Евклида, $\mathrm{L}_{2}$ ).

Первоначально теплофизическая модель подвергается калибровке только по показаниям КТ скважин, потому что именно они дают возможность откалибровать модель, варьируя теплофизические параметры, чтобы получить температурную картину в целом в слое горных пород. На стадии пассивного замораживания и более поздних стадиях (при наличии закрепленного шахтного ствола в модели), выполняется еще один шаг калибровки модели по показаниям термометрических датчиков, расположенных в породе на расстоянии 0,5 м за передовой бетонной крепью, и по данным отдельных замеров в шпурах при подготовке интервалов разреза к тампонажу [10]. В данном случае 
вводится 1-2 дополнительных варьируемых параметра модели: толщина бетонной крепи, ее теплопроводность или коэффициент теплоотдачи на границе бетонной крепи с атмосферой ствола.

Калибровка модели по показаниям датчиков позволяет откорректировать температурное поле лишь во внутреннем кольце ЛПО, между замораживающими колонками и передовым бетоном.

После калибровки модель становится близка к реальной ситуации в пределах допустимой погрешности, определяющей расхождение вычисленных (модельных) и измеренных температур на указанную дату. Ее калибруемые параметры представляют собой некие эквиваленты, в которые заложена вся степень неопределенности информации (погрешности, допущения и упрощения) о параметрах системы «шахтный ствол - породный массив - замораживающие колонки» и протекающих в ней процессах тепломассопереноса, включая указанные выше погрешности и допущения.

\section{Исследование выполнено при финансовой поддержке Министерства науки и образования РФ в рамках соглашения по государственному заданию № 075-03-2021-374 от «29» декабря 2020 г.}

\section{БИБЛИОГРАФИЧЕСКИЙ СПИСОК}

1. Насонов И.Д., Шуплик М.Н. Закономерности формирования ледопородных ограждений при сооружении стволов шахт. - М.: Недра, 1976. - 236 с.: ил.

2. Трупак Н.Г. Замораживание горных пород при проходке стволов. - М.: Углетехиздат, 1954. 896 с.: ил.

3. Ольховиков Ю.П. Крепь капитальных выработок калийных и соляных рудников. - М.: Недра, 1984. $238 \mathrm{c.}$

4. Левин Л.Ю., Семин М.А., Зайцев А.В. Контроль и прогноз формирования ледопородного ограждения с использованием оптоволоконных технологий // Стратегия и процессы освоения георесурсов: сб. науч. тр. Вып. 14 / ГИ УрО РАН. - Пермь, 2016. - С. 236-238.

5. Левин Л.Ю., Семин М.А., Зайцев А.В. Калибровка теплофизических свойств породного массива при моделировании формирования ледопородного ограждения строящихся шахтных стволов // Физикотехнические проблемы разработки полезных ископаемых. - 2019. - № 1. - С. 172-184.

6. Левин Л.Ю., Зайцев А.В., Семин М.А. Контроль теплового режима породного массива на основе применения оптоволоконных технологий мониторинга температур в скважинах // Горное эхо. - 2016. - № 1 (62). - С. 35-37.

7. Семин М.А., Зайцев А.В., Левин Л.Ю. Численное решение обратной задачи Стефана при анализе искусственного замораживания породного массива // Математическое моделирование. - 2021. - Т. 33, №. 2. - C. 93-108. - DOI: 10.20948/mm-2021-02-07.

8. «Frozen Wall»: программа для ЭВМ: свидетельство о гос. регистрации № 2018666337 / Богомягков А.В., Зайцев А.В., Клюкин Ю.А., Левин Л.Ю., Паршаков О.С., Пугин А.В., Семин М.А.; заявитель и правообладатель ПФИЦ УрО РАН. - 2018663501; заявл. 28.11.2018; зарегистрировано 17.12.2018; опубл. 17.12.2018. - $1 \mathrm{c}$.

9. Цытович Н.А. Механика мерзлых грунтов: Общая и прикладная: [учеб. пособие]. - М.: Высш. школа, 1973. - 446 с.: ил.

10. Levin L., Golovatyi I., Zaitsev A., Pugin A., Semin M. Thermal monitoring of frozen wall thawing after artifical ground freezing: Case study of Petrikov Potash Mine // Tunnelling and Underground Space Technology. - 2021. - V. 107. - № статьи 103685. - DOI 10.1016/j.tust.2020.103685. 